\title{
Effects of stage of lactation on protein metabolism in dairy cows
}

\author{
H. Lapierre ${ }^{1,3}$, C.L. Girard ${ }^{1}$, J.J. Matte ${ }^{1}$ and G.E. Lobley ${ }^{2}$ \\ ${ }^{1}$ Agriculture and Agri-Food Canada, \\ Dairy and Swine Research and Development Centre \\ Lennoxville, QC, J1M 1Z3, Canada \\ ${ }^{2}$ Rowett Research Institute, Bucksburn \\ Aberdeen, AB21 9SB, UK
}

(Received 28 January 2005; accepted 31 January 2005)

\begin{abstract}
Forty-two lactating dairy cows were used to determine the interaction between folic acid and methionine dietary supplementation on protein metabolism at 6 and 25 weeks of lactation. Treatments were tested according to a $2 \times 3$ factorial arrangement, with two levels of methionine ( $0 \mathrm{vs} 18 \mathrm{~g}$ of rumen protected methionine) and three levels of folic acid $(0,3$, or $6 \mathrm{mg} / \mathrm{d}$ per $\mathrm{kg}$ of BW of pteroylmonoglutamic acid), equally distributed in 7 blocks of 6 cows each. Whole body leucine kinetics were determined using a constant infusion of $\mathrm{L}\left[1-{ }^{13} \mathrm{C}\right]$ leucine $(1.8 \mathrm{mmol} / \mathrm{h})$. Neither milk production, protein yield or leucine kinetics were affected by treatments. Milk production (45.5 to $35.4 \pm 0.85 \mathrm{~kg} / \mathrm{d}$ ) and protein yield ( 1.43 vs $1.22 \pm 0.028 \mathrm{~kg} / \mathrm{d}$ ) were higher (both $\mathrm{P}<0.001)$ at $6 \mathrm{vs}$ 25 weeks of lactation. However, total whole body leucine irreversible loss rate was not affected by stage of lactation, but fractional oxidation increased as lactation advanced ( 0.136 vs $0.156 \pm 0.0065$; $\mathrm{P}=0.03)$. Whole body protein synthesis was not affected by the stage of lactation $(4.14$ and $4.08 \pm 0.091 \mathrm{~kg} / \mathrm{d}$ ), but the partition of this synthesis was altered, with 0.453 vs $0.403 \pm 0.0095$ $(\mathrm{P}<0.001)$ of leucine used for protein synthesis directed towards milk output. However, absolute rates of non-milk protein synthesis were not affected by the stage of lactation. Although concentrations of IGF-1, insulin and somatotropin varied with stage of lactation, they did not correlate with protein metabolism. In the dairy cow, the high demand for milk production still represents an important portion of the leucine used for protein synthesis until mid-late lactation.
\end{abstract}

KEY WORDS: dairy cow, lactation, folic acid, rumen-protected methionine, leucine, kinetics

\section{INTRODUCTION}

Although it has long been assumed that biosynthesis by ruminal microflora of folic acid, vitamin B-9, was sufficient to cover the requirements of lactating dairy cows, recent work has shown that supplementary folic acid can increase milk and protein

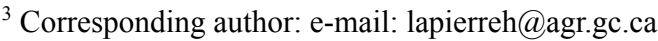


yields and/or milk protein concentration (Girard et al., 1995; Girard and Matte, 1998). As this was observed when estimated supply of methionine did not meet requirements of the lactating dairy cow, the mechanism proposed was that supplementary folic acid improved efficiency of transfer of one-carbon units to direct metabolism of homocysteine to anabolic methionine rather than loss to oxidation through the transsulphuration pathway (Girard and Matte, 2005).

In multiparous cows, the positive effect of folic acid was marked during early lactation but was lost by $200 \mathrm{~d}$ of lactation (Girard and Matte, 1998). This suggests an interaction between folic acid supplementation and stage of lactation related to a possible decreased demand for methionine as lactation progresses. First, in dairy cows, the demand for methionine to support protein synthesis likely decreases as lactation progresses: whole body irreversible loss rates (ILR) of amino acids (which include usage for both protein synthesis and oxidation) decreased with advancing lactation in goats (Riis, 1988; Bequette et al., 1994; Mabjeesh at al., 2000). In addition, the use of methionine as a methyl group precursor may also decline as lactation progresses. During early lactation, both demands for synthesis of glucose and for methylated compounds are increased. As these synthesis share common precursors, such as glycine and serine (Snoswell and Xue, 1987), this may create a shortage in precursors for synthesis de novo of methylated compounds. In such circumstances, part of the methionine supply may provide a direct source of methyl groups, reducing usage of methionine for protein synthesis. This metabolic pressure will lessen as lactation advances.

In growing ruminants, protein metabolism is closely linked to circulating concentrations of hormones such as insulin, IGF-1 and somatotropin (Lobley, 1992). Similarly, these hormones are known to vary with stage of lactation (Vicini et al., 1991) but the relationship between these hormones and protein synthesis in lactating dairy cows is not known.

Therefore, this study was undertaken to examine the interaction between dietary supplements of folic acid and methionine (supplied as a rumen-protected methionine supplement) at two stages of lactation on protein metabolism and to relate any difference to concentrations of hormones related to protein metabolism.

\section{MATERIAL AND METHODS}

\section{Cows and treatments}

Fifty-four multiparous Holstein cows from the dairy herd at the Agriculture and Agri-Food Canada Research Centre (Lennoxville, QC, Canada) were used to determine the effect of folic acid and methionine over a whole lactation. Cows 
were assigned to 9 blocks of 6 cows each, according to their milk production during the previous lactation. During their lactation, all cows received, ad libitum, a total mixed ration containing, on a DM basis, \%: grass silage 20.0, maize silage 20.1, high moisture maize 13.4 , barley 18.9 , wheat 6.0 , soyabean hulls 2.0 , soyabean meal 3.9, protected soyabean meal 3.9, blood meal 1.3, extruded soyabeans 3.8, Megalac ${ }^{\circledR}$ 1.14, tallow 0.43 , urea 0.25 , mineral and vitamin premix 4.9. The chemical composition of the ingredients are given in a companion paper (Girard et al., 2005). The total mixed ration was fed in eight equal meal per day offered every $3 \mathrm{~h}$.

Methionine and folic acid supplementations were tested according to $2 \times 3$ factorial arrangement. Levels of methionine were 0 and $9 \mathrm{~g} / \mathrm{d}$ of Smartamine M (Rhône-Poulenc Animal Nutrition, Mississauga, ON) before calving and $18 \mathrm{~g} / \mathrm{d}$ of Smartamine $\mathrm{M}$ after calving. The basal diet was estimated to supply methionine as $1.75 \%$ of metabolizable protein $(70 \%$ of estimated methionine requirement; NRC, 2001), while the diet plus Smartamine (analysed methionine content $88 \%$, rumen by-pass $91 \%$ and digestibility $98 \%$ ) was estimated to supply methionine at $2.2 \%$ of metabolizable protein. Folic acid levels (Rovimix $10 \%$ pteroylmonoglutamic acid, Hoffmann-LaRoche, Cambridge, ON, Canada) were 0,3 , or $6 \mathrm{mg} / \mathrm{d}$ per $\mathrm{kg}$ of BW of folic acid.

Cows were kept in a tie-stall barn under $16 \mathrm{~h} / \mathrm{d}$ of light $(05.30$ to $21.30 \mathrm{~h})$ and were milked twice daily at 12-h intervals. The experiment began 1 month before the expected time of calving and continued for a 305-d lactation period. Care of cows followed the recommended code of practice of Agriculture Canada (1990) and the guidelines of the Canadian Council of Animal Care (1993).

\section{Sampling procedure}

Seven of the nine blocks, i.e. forty-two cows, were used to determine the effect of treatments and stage of lactation on protein metabolism. At weeks 6 and 25 of lactation, leucine kinetics were determined using a 6 -h primed $(1.8 \mathrm{mmol})$ continuous infusion of $\mathrm{L}\left[1-{ }^{13} \mathrm{C}\right]$ leucine $(1.8 \mathrm{mmol} / \mathrm{h})$ into one jugular vein (from 09.00 to 15.00 ). From the contra-lateral jugular vein, three blood samples were collected before the start of the infusion to determine the natural abundance of ${ }^{13} \mathrm{C}$ in leucine and five hourly samples were collected starting two $\mathrm{h}$ after the beginning of the infusion (from 11.00 to $15.00 \mathrm{~h}$ ). Simultaneous with the blood samples, breath was collected with a face mask, as previously described (Lapierre et al., 1999). In addition, seven hourly samples were collected from the jugular vein, from 09.00 to $15.00 \mathrm{~h}$, to determine insulin and IGF-1 concentrations plus additional samples taken every $30 \mathrm{~min}$ for the determination of somatotropin concentrations. The $\mathrm{CO}_{2}$ production was measured on the preceding day using a 6 -h primed $(0.4 \mathrm{mmol})$ continuous infusion $(0.24 \mathrm{mmol} / \mathrm{h})$ of $\left[{ }^{13} \mathrm{C}\right]$ bicarbonate 
(from 09.00 to $15.00 \mathrm{~h}$ ), with three breath samples collected before the start of the infusion to determine the natural abundance of ${ }^{13} \mathrm{CO}_{2}$. Feed intake and milk production were recorded for six days preceding the infusions and milk was sampled at each milking.

\section{Laboratory analyses}

The isotopic enrichment (IE) of plasma free leucine was determined after deproteinization with sulphosalicylic acid and derivatization with $\mathrm{N}$-(tertbutyldimethysilyl)-N-methyltrifluoroacetate-(MTBSTFA):acetronile (1:1), for $\mathrm{m} / \mathrm{z}$ ions 302, 303 (Trio-1, VG Masslab, Manchester, UK), as described by Calder and Smith (1988). Purified breath $\mathrm{CO}_{2}$ was analysed for $\left[{ }^{13} \mathrm{C}\right] \mathrm{IE}$ for $\mathrm{m} / \mathrm{z}$ ions 44 , 45,46 on a triple collector isotopic ratio mass spectrometer (Sira 12, VG Masslab, Manchester, UK). Isotopic enrichments for leucine and $\mathrm{CO}_{2}$ were corrected for background abundance and expressed as atom percent excess.

Total $\mathrm{N}$ in milk (protein $=\mathrm{N} \times 6.38$ ) was determined using a combustion procedure while total $\mathrm{N}$ in feed was analysed by micro-Kjeldahl method (AOAC, 1984). Double-antibody radioimmunoassays were used to determine concentrations of insulin, somatotropin and IGF-1 (Lapierre et al., 2000a,b). Intraassay and inter-assay coefficients of variation were, respectively, 5.1 and $4.8 \%$ for insulin, 1.6 and $1.6 \%$ for somatotropin, 5.0 and $5.4 \%$ for IGF-1.

\section{Calculation and statistical analyses}

For all given equations, the rate of infusion is $\mathrm{mmol} / \mathrm{h}$ and the IE of the infusate, leucine or $\mathrm{CO}_{2}$ is atom percent excess. Whole body leucine ILR (irreversible loss rate; $\mathrm{mmol} / \mathrm{h}$ ) was calculated as:

$\left(\left(\right.\right.$ rate of leucine infusion $\left.\left.\times \mathrm{IE}_{\text {infusate }}\right) / \mathrm{IE}_{\text {leu }}\right)-\left(\right.$ rate of leucine $\left.\times \mathrm{IE}_{\text {infusate }}\right)$ where $\mathrm{IE}_{\text {leu }}$ represents the IE of the precursor pool, taken as plasma free leucine, calculated as the arithmetic mean of samples taken between 2 to $6 \mathrm{~h}$ of infusion, under plateau conditions.

Whole body leucine oxidation $(\mathrm{mmol} / \mathrm{h})$ was calculated as:

$\left(\mathrm{IE}_{\text {expired CO2 }} \times \mathrm{CO}_{2}\right.$ production $\left.(\mathrm{mmol} / \mathrm{h}) / \mathrm{IE}_{\text {leu }}\right)-\left(\right.$ rate of leucine infusion $\left.\times \mathrm{IE}_{\text {infusate }}\right)$ where the IE of $\mathrm{CO}_{2}$ was measured the day of leucine infusion.

Whole body fractional rate of leucine oxidation (FO) was calculated as: leucine oxidation / ILR

The $\mathrm{CO}_{2}$ production $(\mathrm{mmol} / \mathrm{h})$ was estimated by bicarbonate infusion and calculated as:

$\left(\right.$ rate of bicarbonate infusion $\left.\times \mathrm{IE}_{\text {infusate }} / \mathrm{IE}_{\text {expired CO2 }}\right)-\left(\right.$ rate of infusion $\left.\times \mathrm{IE}_{\text {infusate }}\right)$ where the $\mathrm{IE}$ of $\mathrm{CO}_{2}$ was measured the day of bicarbonate infusion. 
Leucine used for whole body protein synthesis was calculated as the difference between whole body leucine ILR and leucine oxidation. Protein synthesis was then estimated assuming constant fractions of $63 \mathrm{~g}$ of leucine $/ \mathrm{kg}$ of synthesized tissue protein (Lobley et al., 1980) and $98 \mathrm{~g}$ of leucine/kg of milk protein (Swaisgood, 1995). Protein synthesis related to milk synthesis was estimated using milk protein output.

\section{Statistical analyses}

Two cows were removed from statistical analyses, due to health problems not related to the experimental treatments that occurred at calving or in early lactation. Data were analysed using the MIXED procedure of SAS (1999) according to a randomized complete block design with repeated measures in time. The treatment structure was a complete factorial arrangement with two levels of methionine and three levels of folic acid. Results are reported as least squares means and SEM.

\section{RESULTS}

Treatments had no effect $(\mathrm{P}>0.20)$ on any of the leucine kinetics parameters measured. The only effect of treatment was an increase (32.2 to $33.9 \pm 0.38$ $\mathrm{g} / \mathrm{kg} ; \mathrm{P}=0.004$ ) in crude protein concentration in milk with the addition of rumen protected methionine. However, there was no effect of rumen protected methionine $(\mathrm{P}=0.86)$ on protein yield which averaged 1.33 and $1.32 \pm 0.033 \mathrm{~kg} / \mathrm{d}$, for the $0 \mathrm{vs}$ the $18 \mathrm{~g} / \mathrm{d}$ of rumen protected methionine.

As expected, milk production decreased $(\mathrm{P}<0.001)$ from 45.5 to $35.4 \pm 0.85 \mathrm{~kg} / \mathrm{d}$ between wk 6 and 25 of lactation. Over the same period, protein concentration increased (31.4 vs $34.6 \pm 0.35 \mathrm{~g} / \mathrm{kg} ; \mathrm{P}<0.001$ ) while total protein yield decreased ( 1.43 vs $1.22 \pm 0.028 \mathrm{~kg} / \mathrm{d} ; \mathrm{P}<0.001)$. Neither dry matter nor nitrogen intake were affected by stage of lactation and averaged $25.4 \mathrm{vs} 25.0 \pm 0.41 \mathrm{~kg} / \mathrm{d}$ and $670 \mathrm{vs}$ $671 \pm 11.2 \mathrm{~g} / \mathrm{d}$, respectively.

Leucine kinetics are presented in Table 1. The stage of lactation had no effect on whole body leucine ILR, leucine oxidation or total leucine used for protein synthesis. However, the relative partition of ILR was altered by the stage of lactation. Cows at 6 weeks of lactation had a lower fractional oxidation rate of leucine than cows at 25 weeks of lactation ( 0.136 vs $0.156 \pm 0.0065 ; \mathrm{P}=0.03$ ). Whole body protein synthesis decreased numerically in later lactation but with a larger decline for leucine secreted in milk protein $(\mathrm{P}<0.001)$. In consequence, non-milk protein synthesis remained unaltered. Therefore, for cows in early lactation, an increased proportion of their total protein synthesis was towards milk output $(0.453$ vs $0.403 \pm 0.0095 ; \mathrm{P}<0.001)$ with a corresponding reduced proportion as non-milk protein synthesis $(0.547$ 
TABLE 1

Effect of stage of lactation on leucine kinetics in dairy cows ${ }^{1}$

\begin{tabular}{|c|c|c|c|c|}
\hline \multirow{2}{*}{ Leucine kinetics, $\mathrm{mmol} / \mathrm{h}$} & \multicolumn{2}{|c|}{ Stage of lactation, weeks } & \multirow{2}{*}{ SEM } & \multirow{2}{*}{$\mathrm{P}$} \\
\hline & 6 & 25 & & \\
\hline Whole body ILR ${ }^{2}$ & 114.5 & 112.9 & 2.49 & 0.58 \\
\hline Oxidation & 15.9 & 17.7 & 0.95 & 0.13 \\
\hline Fractional oxidation & 0.136 & 0.156 & 0.007 & 0.03 \\
\hline Used for protein synthesis & 98.6 & 95.2 & 1.96 & 0.16 \\
\hline milk protein output & 44.3 & 38 & 0.86 & $<0.001$ \\
\hline non-milk protein synthesis & 54.3 & 57.2 & 1.69 & 0.16 \\
\hline
\end{tabular}

${ }^{1}$ least squares means with pooled SEM

${ }^{2}$ ILR: irreversible loss rate

vs $0.597 \pm 0.0095 ; \mathrm{P}<0.001)$ compared with later lactation. The total amount of protein synthesized averaged 4.14 and $4.08 \pm 0.091 \mathrm{~kg} / \mathrm{d}$, with 1.43 and $1.22 \mathrm{~kg}$ excreted as milk protein at 6 or 25 weeks of lactation, respectively.

TABLE 2

Effect of stage of lactation on hormone concentrations ${ }^{1}$

\begin{tabular}{lccccc}
\hline \multirow{2}{*}{ Hormone } & \multicolumn{2}{c}{ Stage of lactation, weeks } & \multirow{2}{*}{ SEM } & \multirow{2}{*}{ P } \\
\cline { 2 - 3 } & 6 & 25 & & \\
\hline IGF-1, ng/mL & 122.5 & 151.2 & & 5.33 & $<0.001$ \\
Insulin, ng/mL & 0.57 & 0.83 & 0.034 & $<0.001$ \\
Somatotropin, ng/mL & 5.4 & 2.8 & 0.31 & $<0.001$ \\
\hline
\end{tabular}

${ }^{1}$ least squares means with pooled SEM

Insulin and IGF-1 increased $(\mathrm{P}<0.001)$ with stage of lactation while somatotropin decreased ( $\mathrm{P}<0.001$; Table 2). There was no significant correlation between these hormones and ILR or total protein synthesis $\left(\mathrm{r}^{2}<0.20\right.$ with $\left.\mathrm{P}>0.10\right)$.

\section{DISCUSSION}

The absence of treatment effects on protein yield and the impact of methionine on milk protein concentration is consistent with observations made on the whole lactation and has been discussed in the companion paper (Girard et al., 2005). Briefly, the absence of a folic acid effect could be due to the low serum concentrations of vitamin $B_{12}$ measured in these cows, which would restrict methionine synthase activity and lead to 'trapping' of folates as methyltetrahydrofolate. The lack of effect of methionine supplementation may be due to the high dry matter intakes that may override the estimated deficiency of methionine, calculated relative to total protein 
supply and not as a net supply per day. In consequence the major responses in this study relate to the effect of stage of lactation on protein metabolism.

Whole-body leucine ILR in these animals is similar to values previously reported in dairy cows, using plasma leucine as representative of the precursor pool (86 to $121 \mathrm{mmol} / \mathrm{h}$ : Bequette et al., 1996; Lapierre et al., 2002; Thivierge et al., 2002). In parallel with observations on milk protein yield, treatments did not affect protein metabolism. This is the first study, however, to consider how stage of lactation might impact on whole body protein kinetics in dairy cows and where very little effect on ILR was observed. This contrasts with reports in dairy goats, where animals in mid to late lactation had a lower whole body ILR based on either leucine (by $35 \%$ : Riis, 1988; 22\%: Bequette et al., 1994), phenylalanine (by 16\%: Bequette et al., 1994) or lysine (by 38\%: Mabjeesh et al., 2000) compared with goats in early lactation. Such differences highlight the caution needed when extrapolations are made between ruminant species but raise the intriguing question - why are there differences between lactating caprines and bovines? Several possibilities exist with foremost, perhaps, the observation that in the current study neither dry matter nor $\mathrm{N}$ intake decreased during lactation, while in the dairy goat studies, intake was reduced in later lactation. Thus, nutrient supply (including leucine) was maintained throughout lactation in the dairy cows but declined in the goats with a consequent lowering of ILR. Furthermore, ILR is a composite of leucine used for protein synthesis and leucine oxidation, but the latter was not determined in the dairy goat studies. Therefore, it is unknown what component(s) of ILR decreased with advancing lactation in the caprine. In the dairy cows, the lack of change in whole body ILR masked an increase in oxidation, particularly when expressed in fractional terms.

Another explanation for the difference between dairy goats and cows might involve the relative importance of milk production and the temporal changes during the lactation cycle between the species. In the dairy goats, milk production represented a lower proportion of ILR and changes over time were more dramatic, with milk production approximately halved between early and late lactation. In contrast, milk protein output in the current dairy cows decreased by only $14 \%$. Thus, for the dairy cows the proportion of ILR used for milk protein secretion showed a modest decrease during lactation from 0.39 to $0.34 \pm 0.007$, while in the dairy goats studies, the proportion declined from 0.30 to 0.19 (Bequette et al., 1994) or remained unaltered at a much lower proportion (approximately 0.15; Riis, 1988; Mabjeesh et al., 2000).

In agreement with observations in goats by Bequette et al. (1994), the non-milk ILR was not affected by the stage of lactation in the dairy cow. Indeed, the amount of leucine used for non-milk protein synthesis throughout lactation, averaging $55.8 \mathrm{mmol} / \mathrm{h}$, is similar to that observed for cows in later lactation (averaged $55.7 \mathrm{mmol} / \mathrm{h}$ at 210 days in milk) and producing only $16.8 \mathrm{~kg} / \mathrm{d}$ of milk (Lapierre 
et al., 2002). Overall, the efficiencies in excess of $30 \%$ for conversion of whole body protein synthesis to a commercial protein product ensure that the dairy is an efficient ruminant compared to the beef animal, where the ratio of protein retention on synthesized protein is closer to 10\% (Hammond et al., 1987; Lapierre et al., 1999).

Variations of hormones across stage of lactations were as expected based on other literature reports, i.e. a decrease in somatotropin and an increase in IGF-1 and insulin (Vicini et al., 1991). In growing ruminants, relationships between protein synthesis (or degradation) and these hormones have been postulated (Lobley, 1992), but no evidence of similar correlations were found for the current lactating animals. In growing ruminants, IGF-1 concentrations, closely linked with the nutritional status of the animal, match well with anabolic performance. In dairy cows, IGF-1 concentrations, still linked with the nutritional status of the animal, are low during early lactation (Vicini et al., 1991) as the animals are in low or negative balance. However, this period corresponds to the most productive period for the dairy cow and therefore, no correlation can be found between whole body protein synthesis and circulating concentrations of IGF-1. Biological activity of IGF-1 is not only related to circulating concentrations but also to its binding proteins which are related to nutritional status (Lapierre et al., 1995) and probably the stage of lactation. Furthermore, seeking relationships between circulating hormone concentrations and protein anabolism in dairy cows also ignores critical changes in tissue sensitivity to these hormones through lactation, as has been observed for insulin (Vicini et al., 1991). Therefore, a direct link between hormone concentrations and protein synthesis could not be observed in lactating animals across lactation.

In conclusion, whole body ILR of leucine in dairy cow is not altered between early to mid-late lactation, where milk production still represents an important fraction of whole body protein synthesis. Protein synthesis required for other functions than milk output was also not affected by the stage of lactation. Altogether these data reinforce the large contribution that milk protein secretions make to whole body protein synthesis in the high producing dairy cow, making the cow one of the most efficient ruminants for transformation of ingested plant protein into high quality animal protein for human consumption.

\section{ACKNOWLEDGEMENTS}

The authors gratefully thank the staff of the Lennoxville dairy center for taking care of the animals, A.G. Calder, M. Léonard and C. Plante for their dedicated technical support, as well as $\mathrm{S}$. Méthot for statistical analyses. Rumen protected methionine was kindly provided by Rhône-Poulenc Animal Nutrition (Mississauga, ON, Canada) and pteroylmonoglutamic acid by Hoffmann-LaRoche (Cambridge, ON, Canada). Agriculture and Agri-Food Canada, Lennoxville Research Contribution number 853. 


\section{REFERENCES}

Agriculture Canada, 1990. Recommended Code of Practice for Care and Handling of Dairy Cattle. Publ. No. 1853/E, Agriculture Canada. Ottawa, ON

AOAC, 1984. Association of Official Analytical Chemists, Official Methods of Analysis. 14 ${ }^{\text {th }}$ Edition. Arlington, VA

Bequette B.J., Backwell F.R.C., Dhanoa M.S., Walker A., Calder A.G., Wray-Cahen D., Metcalf J.A., Sutton J.D., Beever D.E., Lobley G.E., MacRae J.C., 1994. Kinetics of blood free and milk casein-amino acid labelling in the dairy goat at two stages of lactation. Brit. J. Nutr. 72, 211-220

Bequette B.J., Metcalf J.A., Wray-Cahen D., Backwell F.R.C., Sutton J.D., Lomax M.A., MacRae J.C., Lobley G.E., 1996. Leucine and protein metabolism in the lactating dairy cow mammary gland: responses to supplemental dietary crude protein intake. J. Dairy Res. 63, 209-222

Calder A.G., Smith A., 1988. Stable isotope ratio analysis of leucine and ketoisocaproic acid in blood plasma by gas chromatography/mass spectrometry. Use of tertiary butyldimethylsilyl derivatives. Rapid Commun. Mass. Spectrom. 2, 14-16

Canadian Council on Animal Care, 1993. Guide to the Care and Use of Experimental Animals. Vol. 1. E.D. Offert, B.M. Cross, A.A. McWilliam (Editors). CCAC, Ottawa, Ontario (Canada)

Girard C.L., Lapierre H., Matte J.J., Lobley G.E., 2005. Effects of dietary supplements of folic acid and rumen-protected methionine on lactational performance and folate metabolism of dairy cows. J. Dairy Sci. 88 (in press)

Girard C.L., Matte J.J., 1998. Dietary supplements of folic acid during lactation: effects on the performance of dairy cows. J. Dairy Sci. 81, 1412-1419

Girard C.L., Matte J.J., 2005. Folic acid and vitamin $B_{12}$ requirements of dairy cows: a concept to be revised. Livest. Prod. Sci. (submitted)

Girard C.L., Matte J.J., Tremblay G.F., 1995. Gestation and lactation of dairy cows: a role for folic acid? J. Dairy Sci. 78, 404-411

Hammond A.C., Huntington G.B., Reynolds P.J., Tyrrel H.F., Eisemann J.H., 1987. Absorption, plasma flux and oxidation of L-leucine in heifers at two levels of intake. J. Anim. Sci. 64, 420425

Lapierre H., Bernier J.F., Dubreuil P., Reynolds C.K., Farmer C., Ouellet D.R., Lobley G.E., 1999. The effect of intake on protein metabolism across splanchnic tissues in growing beef steers. Brit. J. Nutr. 81, 457-466

Lapierre H., Bernier J.F., Dubreuil P., Reynolds C.K., Farmer C., Ouellet D.R., Lobley G.E., 2000a. The effect of feed intake level on splanchnic metabolism in growing beef steers. J. Anim. Sci. 78, 1084-1099

Lapierre H., Blouin J.P., Bernier J.F., Reynolds C.K., Dubreuil P., Lobley G.E., 2002. Effect of supply of metabolizable protein on whole body and splanchnic protein metabolism in lactating dairy cows. J. Dairy Sci. 85, 2631-2641

Lapierre H., Farmer C., Reynolds C.K., Bernier J.F., Lobley G.E., Dubreuil P., 2000b. The effect of intake level on whole body kinetics and hepatic removal of somatotropin in growing beef steers. Domest. Anim. Endocrinol. 18, 217-227

Lapierre H., Pelletier G., Abribat T., Fournier K., Gaudreau P., Brazeau P., Petitclerc D., 1995. The effect of intake and growth hormone-releasing factor in lactating dairy cows. J. Dairy Sci. 78, 804-815

Lobley G.E., 1992. Control of the metabolic fate of amino acids in ruminants: a review. J. Anim. Sci. 70, 3264-3275

Lobley G.E., Milne V., Lovie J.M., Reeds P.J., Pennie K., 1980. Whole body and tissue protein synthesis in cattle. Brit. J. Nutr. 43, 491-502 
Mabjeesh S.J., Kyle C.E., Macrae J.C., Bequette B.J., 2000. Lysine metabolism by the mammary gland of lactating goats at two stages of lactation. J. Dairy Sci. 83, 996-1003

National Research Council, 2001. Nutrient Requirements of Dairy Cattle. $7^{\text {th }}$ revised Edition. National Academy Press. Washington, DC

Riis P.M., 1988. Nitrogen balance, amino acid flux rates and rates of whole bod protein synthesis in lactating and in pregnant goats at different intakes. J. Anim. Physiol. Anim. Nutr. 60, 86-95

SAS Institute Inc., 1999. SAS7 User's Guide: Statistics, Version 6 Edition. SAS Inst., Cary, NC

Snoswell A.M., Xue G.-P., 1987. Methyl group metabolism in sheep. Comp. Biochem. Physiol. Pt. B 88, 383-394

Swaisgood H.E., 1995. Protein and amino acid composition of bovine milk. In: R.G. Jensen (Editor). Handbook of Milk Composition. Academic Press, Toronto, ON, pp. 464-468

Thivierge M.C., Petitclerc D., Bernier J.F., Couture Y., Lapierre H., 2002. Variations of mammary metabolism as the udder gradually fills with milk during a 12-h period following milking: leucine kinetics. J. Dairy Sci. 85, 2974-2985

Vicini J.L., Buonomo F.C., Veenhuizen J.J., Miller A.M., Clemmons D.R., Collier R.J., 1991. Nutrient balance and stage of lactation affect responses of insulin, insulin-like growth factors I and II, and insulin-like growth factor-binding protein 2 to somatotropin administration in dairy cows. J. Nutr. 121, 1656-1664

\section{STRESZCZENIE}

\section{Wpływ okresu laktacji na przemianę azotu u krów mlecznych}

Doświadczenie przeprowadzono na 42 krowach mlecznych celem oznaczenia współzależności pomiędzy dodatkiem kwasu foliowego i metioniny do dawek na przemianę azotu w 6 i 25 tygodniu laktacji. Zastosowano układ czynnikowy $2 \times 3$, z dwoma poziomami metioniny ( 0 vs $18 \mathrm{~g}$ chronionej metioniny) i trzema poziomami kwasu foliowego $(0,3$ i $6 \mathrm{mg} /$ dzień $/ \mathrm{kg} \mathrm{m} . \mathrm{c}$.) w postaci kwasu pteroilomonotaminowego, jednakowo podzielonych do 7 bloków, po 6 krów każdy. Kinetykę leucyny w całym ciele oznaczano przy stałej infuzji $\left(1^{-13} \mathrm{C}\right)$ leucyny $(1,8 \mathrm{mmol} /$ godz. $)$. Zastosowane dodatki nie wpłynęły na produkcję mleka i białka oraz kinetykę leucyny. Produkcja mleka (45,5 do $35,4 \pm 0,85$ $\mathrm{kg} / \mathrm{d})$ oraz białka $(1,43 \mathrm{vs} 1,22 \pm 0,028 \mathrm{k} / \mathrm{d})$ były większe (w obydwóch przypadkach $\mathrm{P}<0,001$ ) w 6 niż w 25 tygodniu laktacji. Jednakże tempo nieodwracalnych strat leucyny w całym ciele nie zależało od okresu laktacji, lecz stopień utleniania zwiększał się wraz z postępującą laktacją $(0,136$ vs $0,156 \pm 0,0065 ; \mathrm{P}=0,03)$. Okres laktacji nie miał wpływu na syntezę białka w ciele $(4,14$ i 4,08 \pm $0,91 \mathrm{k} / \mathrm{d})$, lecz względna wartość tej syntezy była zróżnicowana, 0,453 vs $0,403 \pm 0,0095(\mathrm{P}<0,001)$ leucyny wykorzystanej do syntezy białka bezpośrednio wydzielanego w mleku. Bezwzględne tempo (g/d) syntezy białka nie będącego składnikiem mleka było niezależne od okresu laktacji. Chociaż stężenie IGF-1, insuliny i somatotropiny zmieniało się wraz z przebiegiem laktacji, to jednak nie było dobrze skorelowane z przemianą białka. U krów mlecznych, o wysokim zapotrzebowaniu na produkcję mleka, istotna część leucyny używana jest do syntezy białka w środkowym okresie laktacji. 